\title{
Pharmacoeconomic Analysis of Treatment Regimens for Coronavirus Infection Coronavirus Disease-19
}

\author{
Olga Krylova $^{1 *(\mathbb{D})}$, Anatoliy Krasheninnikov ${ }^{2}$, Elza Mamontova² ${ }^{2}$, Galina Tananakina ${ }^{2}$ D, D. Belyakova ${ }^{2}$ (D) \\ ${ }^{1}$ Sechenov First Moscow State Medical University, Moscow, Russia; ${ }^{2}$ Pirogov Russian National Research Medical University, \\ Moscow, Russia
}

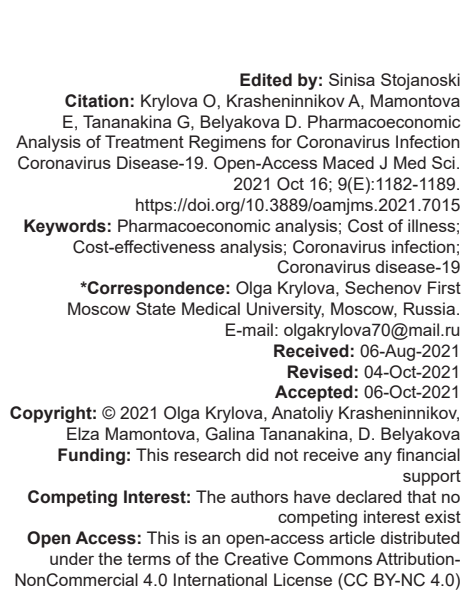

\section{Introduction}

On December 31, 2019, an outbreak of coronavirus disease (COVID)-19 coronavirus infection was reported for the $1^{\text {st }}$ time in Wuhan, China. Then, the prevalence of this disease took on a global scale, and on March 11, 2020, the World Health Organization (WHO) assigned COVID-19 the status of a pandemic. As of the beginning of 2021, the Russian Federation ranks fourth in terms of the prevalence of coronavirus infection. Over the period from March 2020 to February 2021 , more than 84,000 fatal cases of the disease were recorded in Russia [1].

However, the information available at the moment about the results of therapy with existing medications does not allow us to draw an unambiguous conclusion about their effectiveness and safety for the treatment of COVID-19 novel coronavirus infection [2].
Therefore, it is required to assess the feasibility of using the medications proposed for the treatment of the disease from the standpoint of pharmacoeconomics and pharmacoepidemiology.

The purpose of our work is to conduct a pharmacoeconomic analysis of medications recommended by the Ministry of Health of the Russian Federation for the treatment of COVID-19 novel coronavirus infection on an outpatient basis and in an inpatient setting.

\section{Materials and Methods}

In the course of the study, the analysis of the cost of illness including complete treatment regimens in outpatient and inpatient settings was carried out, and 
the analysis of the cost-effectiveness of medications for etiotropic therapy recommended by the Ministry of Health in clinical guidelines (version 10, dated February 8, 2021).

We identified the following cost categories: Direct medical, direct non-medical, and indirect.

Direct medical costs include the cost of medication therapy, the cost of diagnostic procedures, and the cost of providing services by medical professionals.

Direct non-medical costs are determined only for inpatients: Cost of a bed-day (excluding medication therapy costs).

In terms of indirect costs, payments for temporary incapacity for work were calculated.

On an outpatient basis, the cost of individual medications was estimated based on the average prices of pharmacies in the city of Moscow [3].

Since medications are presented on the pharmaceutical market in different forms and dosages, it is recommended to perform calculations based on the active ingredient (Al). However, it should be borne in mind that on an outpatient basis, a patient, as a rule, buys medicines for their own money, and in a pharmacy, medications are sold in whole packages, even if the consumer does not need the full number of units of the particular dosage form. Therefore, a calculation based on the number of packages is also necessary. We took most medications of a low price category and, if possible, with a minimum difference between the required number of units of a dosage form and their number in a real package [4], [5], [6].

The required amount of $\mathrm{Al}$ or packages for a full course for a specific medicinal product was determined based on the dosage regimens recommended by the Ministry of Health of Russia [2].

The cost of individual medications recommended for use in a hospital setting was calculated based on the state register of maximum selling prices (except for remdesivir, which is not included in it). At the same time, the marginal wholesale mark-up allowed for Moscow and the Moscow region, and the value-added tax was added to the indicated prices [7].

The price for remdesivir was obtained from the Rustekhprom distributor.

Since medications from the Vital and Essential Drugs list are presented in different forms and dosages, the calculation was carried out based on the AI [4], [5], [6].

If the treatment regimen assumed relatively equivalent alternative solutions for the medications of symptomatic, pathogenetic, and antibacterial therapies, then the price calculated based on the arithmetic mean was taken for them.

We made a complete list of direct non-medical costs based on the information provided in the temporary clinical guidelines for the diagnosis, prevention, and treatment of COVID-19 coronavirus infection [2].

The cost of each medical intervention was estimated under Appendices 11, 8.2, 6 to the Tariff Agreement for 2020 dated December 30, 2019 [7], [8], [9].

The required number of visits to a medical specialist or diagnostic procedures was also determined based on clinical guidelines and consultation with health professionals. In particular, to assess the length of stay of patients in a hospital, we proposed the following gradation depending on the severity of the disease:

- $\quad$ Mild: 7 days;

- Moderate: 10 days;

- $\quad$ Severe, cytokine storm: 16 days, then the patient switched to another form of the disease; Extremely severe: 5 days on a ventilator, then the patient goes into a serious condition.

Direct non-medical costs, in particular, the cost of a bed (excluding the cost of medication therapy), which amounted to 1500 rubles/day, were estimated based on the average value of the price lists of clinics in the Moscow region.

\section{We also assumed that on average:}

- With outpatient treatment and mild therapy in a hospital, the period of temporary disability (TD) will last 14 days;

- $\quad$ With a moderate form it will last 17 days;

- In severe or extremely severe forms, or with cytokine storm, it will last 30 days.

The further calculation was carried out according to the formulas presented in Table 1.

Table 1: Formulas

\begin{tabular}{|c|c|}
\hline \multicolumn{2}{|l|}{ Direct costs } \\
\hline 1) $\mathrm{By} \mathrm{Al}$ & 2) By package \\
\hline $\begin{array}{l}\text { Cost }(\mathrm{Th})_{\mathrm{a}}=\text { Price }(\mathrm{Th})_{\mathrm{a}}{ }^{*} \mathrm{D}(\mathrm{Th})_{\mathrm{a}}{ }^{*} \mathrm{~T}(\mathrm{Th})(1) \\
\text { where Cost }(\mathrm{Th})_{\mathrm{a}} \text { is the cost of the medication } \\
\text { course, calculated by the Al, rubles; } \\
\text { Price }(\mathrm{Th})_{\mathrm{a}} \text { is the average cost of a unit of the Al } \\
\text { of a medicinal product, rubles; } \\
\mathrm{D}(\mathrm{Th})_{\mathrm{a}} \text { is a single dose of a medication, Al units; } \\
\mathrm{T}(\mathrm{Th}) \text { is the duration of the course of the } \\
\text { medication (10). }\end{array}$ & $\begin{array}{l}\text { Cost }(\mathrm{Th})_{\mathrm{r}}=\text { Price }(\mathrm{Th})_{r}{ }^{*} \mathrm{D}(\mathrm{Th})_{r}(2) \\
\text { where Cost }(\mathrm{Th})_{r} \text { is the cost of the } \\
\text { medication course, calculated by } \\
\text { packages, rubles; } \\
\text { Price }(\mathrm{Th})_{r} \text { is the average cost of a } \\
\text { medication package, rubles; } \\
\mathrm{D}(\mathrm{Th})_{r} \text { is the course dose of the } \\
\text { medication, packages }(10) .\end{array}$ \\
\hline \multicolumn{2}{|c|}{ Indirect costs } \\
\hline \multicolumn{2}{|l|}{ 1) The costs due to TD } \\
\hline \multicolumn{2}{|l|}{$\begin{array}{l}\text { Cost }(T D)=\left(G D P_{d}+T D\right)^{*} n(3) \\
\text { where Cost }(T D) \text { is the costs due to TD, rubles; } \\
G D P_{D} \text { is GDP per capita per day, rubles; } \\
\text { TD is the payment based on TD certificates, rubles; } \\
\mathrm{n} \text { is the number of days of TD [10]. }\end{array}$} \\
\hline 2) The average per capita GDP per year & 3) The average per capita GDP per day \\
\hline $\begin{array}{l}\text { GDP } P_{P}=G D P / P(4) \\
\text { where GDP is the total GDP for the year, rubles; } \\
G D P_{P} \text { is the GDP per capita per year, rubles; } \\
P \text { is the size of the able-bodied population, } \\
\text { people [11]. }\end{array}$ & $\begin{array}{l}G_{d}=G D P_{p} / 365(5) \\
\text { where GDP is GDP per capita per } \\
\text { day, rubles; } \\
G D P_{p} \text { is the GDP per capita per year, } \\
\text { rubles; } \\
365 \text { is the number of days in a year [10]. }\end{array}$ \\
\hline 4) Per capita income & 5) Payments on TD sheets \\
\hline $\begin{array}{l}D_{d}=D_{m} / 30(6) \\
\text { where } D_{d} \text { is the income per capita per day, rubles; } \\
D_{m} \text { is the monthly income per capita, rubles; } \\
30 \text { is the number of days in a month [10]. }\end{array}$ & $\begin{array}{l}T D=D_{d}^{*}(80 / 100)(7) \\
\text { where TD is the payment on TD } \\
\text { sheets, rubles; } \\
D_{d} \text { is the income per capita per day, } \\
\text { rubles [10]. }\end{array}$ \\
\hline
\end{tabular}

Theeffectiveness criterionforcost-effectiveness analysis was determined based on the results of data 
from clinical trials of medications for etiotropic therapy (umifenovir, remdesivir, and favipiravir) on the Internet, in particular, in PubMed, Clinical Trials, Cline Line, Cochrane and Library databases.

Hydroxychloroquine, which is used in Russia as a medication for etiotropic therapy, was recognized as ineffective against coronavirus infection in the framework of the Solidarity study initiated by the WHO. Therefore, it is not advisable to further evaluate it [12].

The main condition for inclusion in the analysis of clinical trials was the completeness of the data provided according to the following criteria: Study design, comparison medications, conditions of randomization, characteristics of participants, presented results, and at least complete information on the primary endpoint.

The list of clinical trials for the above medications with their brief characteristics is presented in Tables 2-4.

The cost-effectiveness ratio was calculated using the following formulas:

Comparative effectiveness research $(\mathrm{CER})=$ Cost/Ef where CER is the cost-effectiveness ratio of the technology;

Cost is the costs associated with technology in monetary terms;

Ef is the clinical effectiveness of the technology, expressed in the appropriate units [11].

$\mathrm{CER}=((\mathrm{DC} 1+\mathrm{IC} 1)-(\mathrm{DC} 2+\mathrm{IC} 2)) /(\mathrm{Ef} 1-\mathrm{Ef} 2)$

Where, CER is an indicator of an increase in cost-effectiveness (demonstrating what additional investments are required to achieve one additional unit of effectiveness when using a more efficient technology);

DC1 is the direct costs when using technology 1 ; technology 1 ;

IC1 is the indirect costs when using

DC2 and IC2 are the direct and indirect costs for technology 2, respectively;

Ef1 and Ef2 are the treatment effects when using technologies 1 and 2, respectively [11].

Evaluation of the medications was carried out for a specific form of coronavirus infection, that is, for a

Table 2: List of clinical trials for the medication with the international non-proprietary name (INN) remdesivir

\begin{tabular}{|c|c|c|c|c|c|c|}
\hline Source & $\begin{array}{l}\text { Number of } \\
\text { patients, age }\end{array}$ & Design of the study & $\begin{array}{l}\text { Duration of the } \\
\text { study }\end{array}$ & Comparison alternative & $\begin{array}{l}\text { The severity of the } \\
\text { disease }\end{array}$ & Primary endpoint \\
\hline [13] & $\begin{array}{l}237(158,79) \\
\geq 18 \text { years }\end{array}$ & $\begin{array}{l}\text { Randomized, double-blind, } \\
\text { placebo-controlled, multicenter } \\
\text { trial }\end{array}$ & 28 days & $\begin{array}{l}\text { Remdesivir + lopinavir-ritonavir, } \\
\text { interferons, corticosteroids, } \\
\text { placebo + lopinavir-ritonavir, } \\
\text { interferons, corticosteroids, }\end{array}$ & Severe form & $\begin{array}{l}\text { Time of clinical improvement up to } 28 \text { days } \\
\text { on a } 6 \text {-point scale of clinical status } \\
\text { ( } 21 \text { - remdesivir, } 23 \text { - placebo) }\end{array}$ \\
\hline [14] & $\begin{array}{l}596(197,199, \\
200), \geq 18 \text { years }\end{array}$ & $\begin{array}{l}\text { Phase } 3 \text { randomized } \\
\text { open-label trial }\end{array}$ & 28 days & $\begin{array}{l}\text { Remdesivir for } 5 \text { days, remdesivir for } \\
10 \text { days, } \\
\text { CT for } 10 \text { days }\end{array}$ & Moderate form & $\begin{array}{l}\text { Clinical status on the } 11^{\text {th }} \text { day on a } 7 \text {-point } \\
\text { scale: } \\
68 \% \text { : Remdesivir for } 10 \text { days, } 74 \% \text { : } \\
\text { Remdesivir for } 5 \text { days, } 64 \% \text { L CT }\end{array}$ \\
\hline [15] & $\begin{array}{l}1062(521,541) \\
\geq 18 \text { years }\end{array}$ & $\begin{array}{l}\text { Randomized, double-blind, } \\
\text { placebo-controlled, multicenter } \\
\text { trial }\end{array}$ & 29 days & Remdesivir, placebo & $\begin{array}{l}\text { Mild, moderate, } \\
\text { severe }\end{array}$ & Recovery time: 10: Remdesivir, 15: Placebo \\
\hline [16] & $61, \geq 18$ years & $\begin{array}{l}\text { Uncontrolled prospective } \\
\text { observational study }\end{array}$ & 28 days & Remdesivir & Severe & $\begin{array}{l}\text { Clinical status on day } 18 \text { (improvement): } \\
68 \%\end{array}$ \\
\hline
\end{tabular}

Table 3: List of clinical trials for the medication with INN favipiravir

\begin{tabular}{|c|c|c|c|c|c|c|}
\hline Source & $\begin{array}{l}\text { Number of patients, } \\
\text { age }\end{array}$ & Design of the study & $\begin{array}{l}\text { Duration of the } \\
\text { study }\end{array}$ & Comparison alternative & $\begin{array}{l}\text { The severity of } \\
\text { the disease }\end{array}$ & Main endpoints \\
\hline [17] & $89(44,45), \geq 16$ years & $\begin{array}{l}\text { Multicenter open-label randomized } \\
\text { trial }\end{array}$ & 45 days & $\begin{array}{l}\text { Favipiravir (immediate and } \\
\text { delayed intake) }\end{array}$ & Mild & $\begin{array}{l}\text { Virus elimination by day } 6: 66.7 \%, 56.1 \% \text {, } \\
\text { elimination by day } 10: 86.1 \%, 83.1 \%\end{array}$ \\
\hline [18] & $80(35,45), \geq 16$ years & $\begin{array}{l}\text { Multicenter open-label randomized } \\
\text { trial }\end{array}$ & 28 days & $\begin{array}{l}\text { Favipiravir+Interferon (IFN) - } \\
\text { alpha, CT, lopinavir/ritonavir + } \\
+ \text { IFN-alpha, CT }\end{array}$ & Severe & $\begin{array}{l}\text { Elimination of the virus on day } 4: 22.86 \% \text {, } \\
17.78 \% \\
\text { Day } 9: 56.25 \%, 35.55 \% \\
\text { Day } 14: 91.43 \%, 62.22 \%\end{array}$ \\
\hline [19] & $\begin{array}{l}236(116,120) \\
\geq 18 \text { years }\end{array}$ & $\begin{array}{l}\text { Prospective, randomized, } \\
\text { controlled, open-label, multicenter } \\
\text { study }\end{array}$ & 17 days & $\begin{array}{l}\text { CT+Favipiravir } \\
\mathrm{CT}+\text { Umifenovir }\end{array}$ & $\begin{array}{l}\text { Mild, moderate } \\
\text { severity }\end{array}$ & $\begin{array}{l}\text { Clinical recovery rates on the seventh day: } \\
71 / 116 ; 62 / 120\end{array}$ \\
\hline [20] & $168(112 ; 56)$ & $\begin{array}{l}\text { Multicenter, open, randomized, } \\
\text { Phase III clinical trial with active } \\
\text { control in outpatients and inpatients }\end{array}$ & 28 days & $\begin{array}{l}\text { Favipiravir } \\
\text { Umifenovir+INF-alpha/ } \\
\text { Hydroxychloroquine+INF } \\
\text { - alpha }\end{array}$ & $\begin{array}{l}\text { Mild, moderate } \\
\text { severity }\end{array}$ & $\begin{array}{l}\text { The median time to achieve elimination of the } \\
\text { virus on day } 3 \text { is } 71.40 \% \text {, } \\
57.10 \% \\
\text { On the } 5^{\text {th }} \text { day: } 81.20 \% \text {, } \\
67.90 \%\end{array}$ \\
\hline
\end{tabular}

Table 4: List of clinical trials for the medication with INN umifenovir

\begin{tabular}{|c|c|c|c|c|c|c|}
\hline Source & Number of patients, age & Design of the study & $\begin{array}{l}\text { Duration of } \\
\text { the study }\end{array}$ & Comparison alternative & $\begin{array}{l}\text { The severity of the } \\
\text { disease }\end{array}$ & Main endpoints \\
\hline $\begin{array}{l}19] \\
\end{array}$ & $236(116,120), \geq 18$ years & $\begin{array}{l}\text { Prospective, randomized, } \\
\text { controlled, open-label, multicenter } \\
\text { study }\end{array}$ & 17 days & $\begin{array}{l}\text { CT+Favipiravir } \\
\text { CT+Umifenovir }\end{array}$ & $\begin{array}{l}\text { Mild, moderate } \\
\text { severity }\end{array}$ & $\begin{array}{l}\text { Clinical recovery rates on the seventh day: } \\
71 / 116 ; 62 / 120\end{array}$ \\
\hline [21] & $\begin{array}{l}86(34,35,17) \\
\geq 18 \text { years }\end{array}$ & $\begin{array}{l}\text { A single-center randomized } \\
\text { controlled trial }\end{array}$ & 21 days & $\begin{array}{l}\text { Lopinavir+Ritonavir, } \\
\text { Umifenovir } \\
\text { No therapy }\end{array}$ & $\begin{array}{l}\text { Mild, moderate } \\
\text { severity }\end{array}$ & $\begin{array}{l}\text { Elimination of the virus on day } 7: 35.3 \%, 37.1 \% \text {, } \\
41.2 \% \\
\text { On day } 14: 85.3 \%, 91.4 \%, 76.5 \%\end{array}$ \\
\hline [22] & $50(34,16), \geq 18$ years & $\begin{array}{l}\text { Single-center randomized } \\
\text { controlled trial }\end{array}$ & 38 days & $\begin{array}{l}\text { Lopinavir/Ritonavir, } \\
\text { Arbidol }\end{array}$ & Moderate severity & $\begin{array}{l}\text { Elimination of the virus on day } 14 \text { : Arbidol: } 100 \% \text {, } \\
\text { lopinavir/ritonavir: } 56.4 \%\end{array}$ \\
\hline
\end{tabular}


mild degree, a comparison of umifenovir and favipiravir is required, and for moderate and severe forms, favipiravir is compared with remdesivir.

\section{Results and Discussion}

\section{The cost of illness analysis}

The cost of medication therapy on an outpatient basis and in a hospital setting is indicated in Tables 5 and 6 , respectively.

As can be seen from Table 5, in most cases, the cost of complete medication therapy is higher when calculated by the number of packages, which justifies our estimate of costs by the number of packages. Exceptions can be explained by the fact that there is a significant difference between the minimum and maximum prices for medications.

Direct medical costs (except for medication therapy) included in the outpatient setting included: Blood draw from a vein, bleeding; study of the erythrocyte sedimentation rate; study of the level of platelets in the blood; blood processing, including registration, an appointment with the district general practitioner (diagnostic, primary, and at home); an appointment with the district general practitioner (diagnostic, repeated, and outpatient visit); test of a blood smear for the analysis of abnormalities in the morphology of erythrocytes, platelets, leukocytes, performing the blood count, pulse oximetry, and polymerase chain reaction (PCR) diagnostics. In addition, for treatment regimens with hydroxychloroquine, electrocardiogram and determination of aspartate transaminase and alanine aminotransferase were taken into account. Furthermore, with a moderate degree, as a rule, an ambulance was called, and computed tomography of one anatomical region was performed in adults (without contrast).
In the hospital setting, for all forms, we took into account the ambulance visit, PCR diagnostics, pulse oximetry, computed tomography, general blood analysis, and consultation with a general practitioner in a hospital. For the moderate form, a coagulogram study is additionally carried out, and a study of the level of protein $\mathrm{C}$, ferritin in the blood, and a biochemical blood test (11 indicators) are performed; for a severe form, consultations of narrow specialists are needed, for an extremely severe form, membrane oxygenation is taken into account.

The level of direct non-medical costs was calculated depending on the severity of the disease:

Mild form: $1500 * 7=10,500$ rubles.

Moderate form: $1500 * 10=15,000$ rubles.

Severe form: $1500 * 21=31,500$ rubles.

Based on statistical data, it was found that the working-age population was 82.264 thousand people, the total GDP per year amounted to 185,534 billion rubles, and the monthly income per capita was $24,381.1$ rubles [21].

Therefore, $\mathrm{GDP}_{\mathrm{p}}=85,534^{*} 10^{6} / 82.264^{*}$ $10^{3}=2,255,348.63$ rubles.

$$
\begin{aligned}
& \mathrm{GDP}_{d}=2,255,348.63 / 365=6179.04 \text { rubles. } \\
& D_{d}=24,381.1 / 30=812.70 \text { rubles. } \\
& T D=812.70 * 0.8=650.16 \text { rubles. } \\
& 650.16 * 14=9102.24 \text { rubles. } \\
& 650.16 * 17=11,052.72 \text { rubles. } \\
& 650.16 * 30=19,504.80 \text { rubles. }
\end{aligned}
$$

Thus, the total costs of outpatient and inpatient therapy are presented in Tables 7 and 8 , respectively.

Thus, it can be concluded that, in an outpatient setting, for all forms of the disease, treatment regimens

\begin{tabular}{|c|c|c|c|c|}
\hline Form & Medications & $\begin{array}{l}\text { Costs-1 (by number } \\
\text { of packages) }\end{array}$ & $\begin{array}{l}\text { Costs-2 } \\
\text { (by Al) }\end{array}$ & $\begin{array}{l}\text { The difference in the value } \\
\text { of costs ( } 1 \text { vs. } 2), \%\end{array}$ \\
\hline \multicolumn{5}{|l|}{ Mild } \\
\hline \multirow[t]{2}{*}{ Treatment regimen 1} & \multirow[t]{2}{*}{ Favipiravir, INF-alpha (intranasal), paracetamol } & $11,476.50$ & $10,360.00$ & 10.78 \\
\hline & & $12,702.38$ & $13,080.00$ & -2.89 \\
\hline Treatment regimen 2 & Hydroxychloroquine, INF-alpha (intranasal), paracetamol & 1401.45 & 1440.00 & -2.68 \\
\hline Treatment regimen 3 & Umifenovir, INF-alpha (intranasal), paracetamol & 2153.27 & 2352.00 & -8.45 \\
\hline \multicolumn{5}{|l|}{ Moderate (without pneumonia) } \\
\hline \multirow[t]{2}{*}{ Treatment regimen 1} & \multirow[t]{2}{*}{ Favipiravir, INF-alpha (intranasal), paracetamol, Rivaroxaban OR Apixaban } & $14,841.81$ & $13,080.25$ & 13.47 \\
\hline & & $16,067.69$ & $15,800.25$ & 1.69 \\
\hline Treatment regimen 2 & $\begin{array}{l}\text { Hydroxychloroquine, INF-alpha (intranasal), Paracetamol, Rivaroxaban OR } \\
\text { Apixaban }\end{array}$ & 4766.76 & 4160.25 & 14.58 \\
\hline $\begin{array}{l}\text { Antibacterial therapy } \\
\text { (according to indications) }\end{array}$ & $\begin{array}{l}\text { Amoxicillin + clavulanic acid OR amoxicillin OR azithromycin OR levofloxacin } \\
\text { OR moxifloxacin OR clarithromycin }\end{array}$ & 812.68 & 803.85 & 1.10 \\
\hline \multicolumn{5}{|l|}{ Moderate with pneumonia } \\
\hline \multirow[t]{2}{*}{ Treatment regimen 1} & \multirow{2}{*}{$\begin{array}{l}\text { Favipiravir, rivaroxaban OR apixaban, dexamethasone OR prednisolone OR } \\
\text { methylprednisolone }\end{array}$} & $14,574.09$ & $12,467.15$ & 16.90 \\
\hline & & $15,799.97$ & $15,187.15$ & \\
\hline Treatment regimen 2 & $\begin{array}{l}\text { Hydroxychloroquine, rivaroxaban OR apixaban, dexamethasone OR } \\
\text { prednisolone OR methylprednisolone }\end{array}$ & 4499.04 & 3547.15 & 4.04 \\
\hline $\begin{array}{l}\text { Antibacterial therapy } \\
\text { (according to indications) }\end{array}$ & $\begin{array}{l}\text { Amoxicillin + clavulanic acid OR amoxicillin OR azithromycin OR levofloxacin } \\
\text { OR moxifloxacin OR clarithromycin }\end{array}$ & 812.68 & 803.85 & 26.84 \\
\hline
\end{tabular}
with hydroxychloroquine will be the most beneficial from the economic point of view. The most expensive medication from the consumer's point of view is favipiravir.

Table 5: Costs for a full course of medication therapy per one person on an outpatient basis 
In a hospital setting, for mild-to-moderate forms, the use of hydroxychloroquine is also the least expensive alternative. The most expensive medication is the medication with INN remdesivir.

For severe and extremely severe forms, only one treatment regimen with INN is presented (favipiravir).

Regimens for the treatment of cytokine storms cannot be unambiguously compared, since their use is largely determined by the individual characteristics of the patient.

\section{Cost-effectiveness analysis}

To evaluate favipiravir and umifenovir, study No. 3 from Table 3 was selected since there is a direct comparison of these medications. The criterion of effectiveness is the frequency of complete elimination of the virus on day 7 (Tables 9 and 10).

The effectiveness coefficient is calculated according to formula 8 , presented in the Materials and methods section.

If we focus only on the CER value, then the use of umifenovir is the most profitable in terms of cost-effectiveness ratio, since fewer costs are required to treat one person. However, the study found that the favipiravir contributed to the complete elimination of the virus in a larger number of people, therefore, incremental analysis is required to assess the increment of the costbenefit unit according to formula 9:

$\operatorname{CER}=(986,000-119,381) /(61-52)=96,291$

The resulting number is, therefore, the added cost of increasing the number of recoveries per 100 people/week using favipiravir.

To evaluate favipiravir and remdesivir, no studies were conducted that were completely identical in design and endpoints, therefore, based on the maximum possible similarity of endpoints, study No. 2 and No. 2 from Tables 2 and 3, respectively, were selected.

The effectiveness criterion is the frequency of complete virus elimination on day 11 in the remdesivir group and the frequency of complete virus elimination on day 9 in the favipiravir group (Tables 11 and 12).

The effectiveness coefficient is calculated according to formula 1 presented in section 2.1 .

Table 6: Costs for a full course of medication therapy per one person in a hospital setting

\begin{tabular}{|c|c|c|c|}
\hline Form & Medications & & Costs \\
\hline \multirow[t]{4}{*}{ Mild } & Treatment regimen 1 & Favipiravir, INF-alpha (intranasal), enoxaparin sodium & $14,234.37$ \\
\hline & & & $16,654.37$ \\
\hline & Treatment regimen 2 & Hydroxychloroquine, INF-alpha (intranasal), enoxaparin sodium & 5965.01 \\
\hline & Treatment regimen 3 & Umifenovir, INF-alpha (intranasal), enoxaparin sodium & 6958.17 \\
\hline \multirow[t]{8}{*}{ Moderate } & Treatment regimen 1 & Favipiravir, baricitinib OR tofacitinib, enoxaparin sodium & $47,714.80$ \\
\hline & & & $50,134.80$ \\
\hline & Treatment regimen 2 & Remdesivir, baricitinib OR tofacitinib, enoxaparin sodium & $149,244.80$ \\
\hline & Treatment regimen 3 & Hydroxychloroquine, baricitinib OR tofacitinib, enoxaparin sodium & $39,445.44$ \\
\hline & Treatment regimen 4 & Favipiravir, olokizumab OR levilimab, enoxaparin sodium & $65,645.00$ \\
\hline & & & $68,065.00$ \\
\hline & Treatment regimen 5 & Remdesivir, olokizumab OR levilimab, enoxaparin sodium & $167,175.00$ \\
\hline & Treatment regimen 6 & $\begin{array}{l}\text { Hydroxychloroquine, olokizumab OR levilimab, enoxaparin } \\
\text { sodium }\end{array}$ & $57,375.64$ \\
\hline $\begin{array}{l}\text { Severe (pneumonia with respiratory insufficiency (RI) or } \\
\text { acute respiratory distress syndrome (ARDS)) }\end{array}$ & Treatment regimen 1 & Favipiravir, tocilizumab OR sarilumab, enoxaparin sodium & $163,981.46$ \\
\hline \multirow[t]{6}{*}{ Cytokine storm } & Treatment regimen 1 & $\begin{array}{l}\text { Methylprednisolone, tocilizumab OR sarilumab, enoxaparin } \\
\text { sodium }\end{array}$ & $156,382.38$ \\
\hline & Treatment regimen 2 & Dexamethasone, tocilizumab OR sarilumab, enoxaparin sodium & $155,733.18$ \\
\hline & Treatment regimen 3 & Dexamethasone, canakinumab, enoxaparin sodium & $2,403,397.23$ \\
\hline & Treatment regimen 4 & Methylprednisolone, canakinumab, enoxaparin sodium & $2,404,046.43$ \\
\hline & Treatment regimen 5 & Methylprednisolone OR dexamethasone, enoxaparin sodium & 5370.18 \\
\hline & Treatment regimen 6 & Tocilizumab OR sarilumab OR canakinumab, Enoxaparin sodium & $155,511.46$ \\
\hline
\end{tabular}

Table 7: The results of the cost of illness analysis per one person in an outpatient setting

\begin{tabular}{|c|c|c|c|}
\hline Form & Medications & & Costs \\
\hline \multirow[t]{4}{*}{ Mild } & Treatment regimen 1 & Favipiravir, INF-alpha (intranasal), enoxaparin sodium & $14,234.37$ \\
\hline & & & $16,654.37$ \\
\hline & Treatment regimen 2 & Hydroxychloroquine, INF-alpha (intranasal), enoxaparin sodium & 5965.01 \\
\hline & Treatment regimen 3 & Umifenovir, INF-alpha (intranasal), enoxaparin sodium & 6958.17 \\
\hline \multirow{6}{*}{ Moderate } & & & $50,134.80$ \\
\hline & Treatment regimen 2 & Remdesivir, baricitinib OR tofacitinib, enoxaparin sodium & $149,244.80$ \\
\hline & Treatment regimen 3 & Hydroxychloroquine, baricitinib OR tofacitinib, enoxaparin sodium & $39,445.44$ \\
\hline & Treatment regimen 4 & Favipiravir, olokizumab OR levilimab, enoxaparin sodium & $65,645.00$ \\
\hline & & & $68,065.00$ \\
\hline & Treatment regimen 6 & Hydroxychloroquine, olokizumab OR levilimab, enoxaparin sodium & $57,375.64$ \\
\hline Severe (pneumonia with RI, ARDS) & Treatment regimen 1 & Favipiravir, tocilizumab OR sarilumab, enoxaparin sodium & $163,981.46$ \\
\hline \multirow[t]{7}{*}{ Cytokine storm } & Treatment regimen 1 & Methylprednisolone, tocilizumab OR sarilumab, enoxaparin sodium & $156,382.38$ \\
\hline & Treatment regimen 2 & Dexamethasone, tocilizumab OR sarilumab, enoxaparin sodium & $155,733.18$ \\
\hline & Treatment regimen 3 & Dexamethasone, canakinumab, enoxaparin sodium & $2,403,397.23$ \\
\hline & Treatment regimen 4 & Methylprednisolone, canakinumab, enoxaparin sodium & $2,404,046.43$ \\
\hline & Treatment regimen 5 & Methylprednisolone OR dexamethasone, enoxaparin sodium & 5370.18 \\
\hline & Treatment regimen 6 & Tocilizumab OR sarilumab OR canakinumab, enoxaparin sodium & $155,511.46$ \\
\hline & & & $2,403,175.51$ \\
\hline
\end{tabular}


Table 8: The results of the cost of disease analysis in a hospital setting for one person

\begin{tabular}{|c|c|c|c|c|}
\hline Form & Treatment regimen & Cost category & Costs, rubles & Total costs, rubles \\
\hline \multirow[t]{9}{*}{ Mild } & \multirow[t]{3}{*}{ Treatment regimen 1 (with favipiravir) } & Direct medical & $24,123.35$ & \multirow[t]{3}{*}{$55,103.47$} \\
\hline & & Direct non-medical & $10,500.00$ & \\
\hline & & Indirect & 9102.24 & \\
\hline & \multirow[t]{3}{*}{ Treatment regimen 2 (with hydroxychloroquine) } & Direct medical & $14,839.29$ & \multirow[t]{3}{*}{$34,441.53$} \\
\hline & & Direct non-medical & $10,500.00$ & \\
\hline & & Indirect & 9102.24 & \\
\hline & \multirow[t]{3}{*}{ Treatment regimen 1 (with umifenovir) } & Direct medical & $15,637.15$ & \multirow[t]{3}{*}{$35,239.39$} \\
\hline & & Direct non-medical & $10,500.00$ & \\
\hline & & Indirect & 9102.24 & \\
\hline \multirow[t]{18}{*}{ Moderate } & \multirow[t]{3}{*}{ Treatment regimen 1 (with favipiravir + kinase inhibitor) } & Direct medical & $62,507.42$ & \multirow[t]{3}{*}{$88,560.14$} \\
\hline & & Direct non-medical & $15,000.00$ & \\
\hline & & Indirect & $11,052.72$ & \\
\hline & \multirow[t]{3}{*}{ Treatment regimen 2 (with remdesivir + kinase inhibitor) } & Direct medical & $162,827.42$ & \multirow[t]{3}{*}{$188,880.14$} \\
\hline & & Direct non-medical & $15,000.00$ & \\
\hline & & Indirect & $11,052.72$ & \\
\hline & \multirow[t]{3}{*}{ Treatment regimen 3 (with hydroxychloroquine + kinase inhibitor) } & Direct medical & $53,223.36$ & \multirow[t]{3}{*}{$79,276.08$} \\
\hline & & Direct non-medical & $15,000.00$ & \\
\hline & & Indirect & $11,052.72$ & \\
\hline & \multirow{3}{*}{ Treatment regimen 4 (with favipiravir + monoclonal antibodies [MAs]) } & Direct medical & $81,647.62$ & \multirow[t]{3}{*}{$107,700.34$} \\
\hline & & Direct non-medical & $15,000.00$ & \\
\hline & & Indirect & $11,052.72$ & \\
\hline & \multirow[t]{3}{*}{ Treatment regimen 5 (with remdesivir $+\mathrm{MA}$ ) } & Direct medical & $180,757.62$ & \multirow[t]{3}{*}{$206,810.34$} \\
\hline & & Direct non-medical & $15,000.00$ & \\
\hline & & Indirect & $11,052.72$ & \\
\hline & \multirow[t]{3}{*}{ Treatment regimen 6 (with hydroxychloroquine $+\mathrm{MA}$ ) } & Direct medical & $71,153.56$ & $97,206.28$ \\
\hline & & Direct non-medical & $15,000.00$ & \\
\hline & & Indirect & $11,052.72$ & \\
\hline Severe & Treatment regimen 1 (with favipiravir) & Direct medical & $199,114.96$ & $250,119.76$ \\
\hline & & Direct non-medical & $31,500.00$ & \\
\hline & & Indirect & $19,504.80$ & \\
\hline Extremely & Treatment regimen 1 (with favipiravir) & Direct medical & $623,137.09$ & $674,141.89$ \\
\hline severe & & Direct non-medical & $31,500.00$ & \\
\hline & & Indirect & $19,504.80$ & \\
\hline Cytokine storm & Treatment regimen 1 & Direct medical & $188,322.67$ & $239,327.47$ \\
\hline & & Direct non-medical & $31,500.00$ & \\
\hline & & Indirect & $19,504.80$ & \\
\hline & Treatment regimen 2 & Direct medical & $187,673.47$ & $238,678.27$ \\
\hline & & Direct non-medical & $31,500.00$ & \\
\hline & & Indirect & $19,504.80$ & \\
\hline & Treatment regimen 3 & Direct medical & $2,435,337.52$ & $2,486,342.32$ \\
\hline & & Direct non-medical & $31,500.00$ & \\
\hline & & Indirect & $19,504.80$ & \\
\hline & Treatment regimen 4 & Direct medical & $2,435,986.72$ & $2,486,991.52$ \\
\hline & & Direct non-medical & $31,500.00$ & \\
\hline & & Indirect & $19,504.80$ & \\
\hline & Treatment regimen 5 (in case of contraindications to genetically & Direct medical & $37,310.47$ & $88,315.27$ \\
\hline & engineered medications) & Direct non-medical & $31,500.00$ & \\
\hline & & Indirect & $19,504.80$ & \\
\hline & Treatment regimen 6 (in case of contraindications to hyaluronic acid & Direct medical & $187,451.75$ & $238,456.55$ \\
\hline & $(\mathrm{HA}))$ & & (MA) & $2,486,120.60$ \\
\hline & & & $2,435,115.80$ & \\
\hline & & & (Canakinumab) & \\
\hline & & Direct non-medical & $31,500.00$ & \\
\hline & & Indirect & $19,504.80$ & \\
\hline
\end{tabular}

Table 9: Required information on the clinical trial for the umifenovir and favipiravir medications

\begin{tabular}{llll}
\hline Medication & Number of people & Observed effect, \% & $\begin{array}{l}\text { The cost of the medication for one } \\
\text { person, rub }\end{array}$ \\
\hline Favipiravir & 116 & $71 / 116,61.2 \%$ & 9860.00 \\
Umifenovir & 120 & $62 / 120,51.67 \%$ & 1193.81 \\
\hline
\end{tabular}

Therefore, in this case, the cheapest and most effective alternative is favipiravir. Therefore, incremental analysis is not required.

Table 10: Results of the cost-effectiveness analysis for umifenovir and favipiravir

\begin{tabular}{llll}
\hline Medication & Number of people & $\begin{array}{l}\text { Observed effect } \\
\text { (out of 100 people) }\end{array}$ & CER \\
\hline Favipiravir & 100 & 61 & $986,000 / 61=16,163.93$ \\
Umifenovir & 100 & 52 & $119,381 / 52=2295.79$ \\
\hline
\end{tabular}

\section{Conclusion}

In the course of the cost of illness analysis, calculations and estimates of direct medical, direct non-medical, and indirect costs were carried out. As a result of this study, it was found that the most

Table 11: Required information on the clinical trial for remdesivir and favipiravir

\begin{tabular}{llll}
\hline Medication & Number of people & Observed effect, \% & $\begin{array}{l}\text { The cost of the medication for one } \\
\text { person, rub }\end{array}$ \\
\hline Remdesivir 199 & $49.24 \%$ & 110,000 \\
Favipiravir & 80 & $56.25 \%$ & 9860.00 \\
\hline
\end{tabular}

appropriate from an economic point of view is the use of hydroxychloroquine for the treatment of mild and moderate forms of infection.

Table 12: Results of the cost-effectiveness analysis for remdesivir and favipiravir

\begin{tabular}{llll}
\hline Medication & Number of people & $\begin{array}{l}\text { Observed effect (out of } \\
100 \text { people) }\end{array}$ & CER \\
\hline Favipiravir & 100 & 56 & $986,000 / 56=17,607.14$ \\
Remdesivir & 100 & 49 & $11,000,000 / 49=224,489.79$ \\
\hline
\end{tabular}

However, the cost-effectiveness analysis found that the use of this medication as an etiotropic therapy is not justified. Therefore, according to the results of the study, the most effective medication for the treatment of moderate and severe forms is favipiravir. When conducting a similar analysis for the 
mild form, an ambiguous result was obtained: The most effective medication is also favipiravir, and umifenovir, which has lower effectiveness, but at the same time a lower price, has the lowest cost-effectiveness ratio, which is more appropriate from the point of view of pharmacoeconomical studies.

\section{References}

1. Dong E, Du H, Gardner L. An interactive web-based dashboard to track COVID-19 in real time. Lancet Infect Dis. 2020;20(5):533-4. https://doi.org/10.1016/s1473-3099(20)30120-1 PMid:32087114

2. Ministry of Health of the Russian Federation. Prevention, diagnostics and treatment of new coronavirus infection (COVID-19): Temporarymethodological recommendations;2021. Available from: https://www.static-0.minzdrav.gov.ru/system/ attachments/attaches/000/054/662/original/\%D0\%92\%D1\% 80\%D0\%B5\%D0\%BC\%D0\%B5\%D0\%BD\%D0\%BD\%D1\% 8B\%D0\%B5_\%D0\%9C\%D0\%A0_COVID-19_\%28v.10\%29. pdf. [Last accessed on 2021 Oct 04].

3. Farmindex RF. Nivolumabum; 2021. Available from: https://www. pharmindex.ru/opdivo.html. [Last accessed on 2021 Oct 04].

4. Belousov DY, Zyryanov SK, Kolbin AS, editors. Inclusion of Medications in Restrictive Lists: A Step-by-step Algorithm. Moscow: Izdatelstvo OKI, Buki Vedi; 2019.

5. Federal State Budgetary Institution "Center of Expertise and Control of Medical Assistance Quality" (FGBU TsEKKMP) of the Ministry of Health of Russia. Methodological Recommendations for Conducting a Comparative Clinical and Economic Assessment of a Medicinal Product (New Edition). Moscow: Utverzhdeny Prikazom FGBU TsEKKMP Minzdrava Rossii ot 29.12.2018 No. 242-od Approved by Order No. 242-od of the Federal State Budgetary Institution Center of Expertise and Control of Medical Assistance Quality (FGBU TsEKKMP) of the Ministry of Health of Russia; 2018. Available from: https://www. rosmedex.ru/wp-content/uploads/2019/06/MR-KE\%60I_novayaredaktsiya_2018-g..pdf. [Last accessed on 2021 Oct 04]

6. Federal State Budgetary Institution "Center of Expertise and Control of Medical Assistance Quality" (FGBU TsEKKMP) of the Ministry of Health of Russia. Methodical Recommendations for Calculating Costs when Conducting Clinical and Economic Studies of Medications. Utverzhdeny prikazom FGBU TsEKKMP Minzdrava Rossii ot 29.12.2017 No. 185-od Approved by order No. 185-od of the Federal State Budgetary Institution "Center of Expertise and Control of Medical Assistance Quality" (FGBU TsEKKMP) of the Ministry of Health of Russia; 2017. Available from: https://www.rosmedex.ru/wp-content/uploads/2018/02/ Metodicheskie-rekomendatsii-po-raschetu-zatrat-pri-provedeniikliniko-e\%60konomicheskih-issledovaniy-lekarstvennyihpreparatov-2017.pdf. [Last accessed on 2021 Oct 04].

7. Moscow City Fund of Compulsory Health Insurance. Prilozhenie No. 11 k Tarifnomu soglasheniyu na 2020 god ot 30 dekabrya 2019 goda. Tarify na oplatu skoroi meditsinskoi pomoshchi, okazannoi vne meditsinskoi organizatsii v ramkakh Territorialnoi programmy OMS [Appendix No. 11 to the Tariff Agreement for 2020 dated December 30, 2019. Tariffs for payment of emergency medical care provided outside a medical organization within the framework of the Territorial compulsory medical insurance program] [Internet]. 2019. Available from: https://www.mgfoms. ru/sites/default/files/prilozhenie_no_35_k_dok._no_05-0002_20-4_ot_10.01.2020_o_prilozhenie_no_11_k_tarifnomu_ soglasheniyu_na_202_12146935_v1.pdf
8. Moscow City Fund of Compulsory Health Insurance. Prilozhenie No. 6 k Tarifnomu Soglasheniyu na 2020 God ot 30 Dekabrya 2019 Goda. Tarify Na Oplatu Meditsinskoi Pomoshchi, Okazyvaemoi $v$ Ambulatornykh Usloviyakh $v$ Ramkakh Territorialnoi Programmy OMS, Primenyaemye, v Tom Chisle Dlya Osushchestvleniya Gorizontalnykh Raschetov (za Isklyucheniem Profilya "Stomatologiya") Appendix No. 6 to the Tariff Agreement for 2020. Tariffs for Payment of Medical Care Provided on an Outpatient Basis Within the Framework of the Territorial Compulsory Medical Insurance Program Used Among Other Things for Horizontal Settlements (Except for the "Dentistry" Profile); 2019. Available from: https://www.mgfoms.ru/sites/ default/files/prilozhenie_no_21_k_dok._no_05-00-02_20-4_ ot 10.01.2020_o_prilozhenie_no_6_k_tarifnomu_soglasheniyu na_2020_12146744_v1.pdf. [Last accessed on 2021 Oct 04].

9. Moscow City Fund of Compulsory Health Insurance. Prilozhenie No. 8.2 k Tarifnomu Soglasheniyu na 2020 God ot 30 Dekabrya 2019 Goda. Tarify na Oplatu Meditsinskoi Pomoshchi, Okazyvaemoi v Statsionarnykh Usloviyakh po Otdelnym Meditsinskim Uslugam v Ramkakh Territorialnoi Programmy OMS. Appendix No. 8.2 to the Tariff Agreement for 2020. Tariffs for Payment for Medical Care Provided in Inpatient Conditions for Certain Medical Services Under the Territorial Compulsory Medical Insurance Program; 2019. Available from: https://www.mgfoms.ru/sites/ default/files/prilozhenie_no_27_k_dok._no_05-00-02_20-4 ot_10.01.2020_o_prilozhenie_no_8.2_k_tarifnomu_soglasheniyu_ na_20_12146893_v1.pdf. [Last accessed on 2021 Oct 04].

10. Yagudina RI, Serpik VG. Methodology of cost analysis. Farmakoekon Teor Prakt. 2016;4(2):5-9.

11. Yagudina RI, Serpik VG, Sorokovikov IV. The methodological basics of the cost-effectiveness analysis. Farmakoekon Teor Prakt. 2014;2(2):23-6.

12. World Health Organization. Koronavirus COVID-19 COVID-19 Coronavirus; 2021. Available from: https://www.who. int/ru/emergencies/diseases/novel-coronavirus-2019.

13. Wang $Y$, Zhang D, Du G, Du R, Zhao J, Jin $Y$, et al Remdesivir in adults with severe COVID-19: A randomised, double-blind, placebo-controlled, multicentre trial. Lancet. 2020;395(10236):1569-78. https://doi.org/10.1016/ s0140-6736(20)31022-9

14. Spinner CD, Gottlieb RL, Criner GJ, Arribas López JR, Cattelan AM, Viladomiu AS, et al. Effect of remdesivir vs standard care on clinical status at 11 days in patients with moderate COVID-19. JAMA. 2020;324(11):1048. https://doi. org/10.1001/jama.2020.16349

PMid:32821939

15. NIAID. Adaptive COVID-19 Treatment Trial (ACTT); 2020. Available from: https://www.clinicaltrials.gov/ct2/show/ NCT04280705. [Last accessed on 2021 Oct 04].

16. Augustin M, Hallek M, Nitschmann S. Remdesivir bei Patienten mit schwerer COVID-19. Internist. 2020;61(6):644-5. https://doi. org/10.1007/s00108-020-00800-5

17. JRCT. Favipiravir for SARS-CoV-infected Patients. Japan Register of Clinical Trials; 2020. Available from: https:// www.jrct.niph.go.jp/en-latest-detail/jRCTs041190120. [Last accessed on 2021 Oct 04].

18. Cai Q, Yang M, Liu D, Chen J, Shu D, Xia J, et al. Experimental treatment with Favipiravir for COVID-19: An open-label control study. Engineering. 2020;6(10):1192-8. https://doi.org/10.1016/j. eng.2020.03.007 PMid:32346491

19. Chen $C$, Zhang $Y$, Huang J, Yin $P$, Cheng Z, Wu J, et al. Favipiravir versus Arbidol for COVID-19: A randomized clinical trial. MedRxiv. 2020. https://doi.org/10.1101/2020.03.1 7.20037432

20. Ruzhentsova TA, Chukhlyaev PV, Khavkina DA, Garbuzov AA, Ploskireva AA, Oseshnyuk RA, et al. Efficacy and safety of favipiravir in a complex therapy of mild to moderate 
COVID-19. Infect Dis News Opin Train. 2020;9(4):26-38. https:// doi.org/10.33029/2305-3496-2020-9-4-26-38

21. Zhu Z, Lu Z, Xu T, Chen C, Yang G, Zha T, et al. Arbidol monotherapy is superior to lopinavir/ritonavir in treating COVID-19. J Infect. 2020;81(1):e21-3. https://doi.org/10.1016/j. jinf.2020.03.060

PMid:32283143
22. Li Y, Xie Z, Lin W, Cai W, Wen C, Guan Y, et al. Efficacy and safety of Lopinavir/Ritonavir or Arbidol in adult patients with mild/moderate COVID-19: An exploratory randomized controlled trial. Med (N Y). 2020;1(1):105-13.e4. https://doi.org/10.1016/j. medj.2020.04.001

PMid:32838353 